\title{
陰解法弾塑性計算アルゴリズムを用いた微小変形土/水連成有限要素法解析
}

Finite element method analysis of soil/water coupling problems using implicit elasto - plastic calculation algorithm

\author{
矢富盟祥*, 鱸 洋一** \\ Chikayoshi Yatomi, Yoichi Suzuki
}

*正会員 Ph. D. 金沢大学教授, 工学部土木建設工学科（广920-8667 石川県金沢市小立野 2-40-20)

**正会員 博士 (工学) 五大開発株式会社 応用工学研究所（广921-8051 石川県金沢市黒田 1-31）

In this paper, we examine a new method of implicit finite element analysis of soil / water coupling problems. It consists of two main schemes: One scheme is an implicit return mapping scheme and another is a scheme which employs the consistent tangential modulus. The implicit return mapping scheme is based on the notion of the elastic-plastic operator split that consists of the elastic predictor and the plastic corrector. A tangential modulus consisting with the integration algorithm is developed for a well-known Cam-clay model for soils. Some examples of the implicit method show the high accuracy and much reducing the total CPU time.

Key Words: soil/water coupling problem, Cam-clay, return mapping, implicit method, consistent tangential modulus

1. はじめに

近年の目覚しい計算機の小型化, 高速化に伴い, 近 い将来, 地盤工学の分野においても現場レベルの設計 に対して有限要素法などの数值解析を導入することが 可能となり,その必要性・重要性が認識されている. そ の実用化のためには地盤のモデル化, 数值解析手法 の検証, 現地調查からのデータサンプリング技術などの 総合的な整備がますます必要不可欠となる. 本論文で は軟弱地盤の圧密沈下, 盛土施工の土地盤の設計な ぞに有効である土／水連成数值解析の精度の向上, 計 算時間の短縮を目的に新たに陰解法弾塑性計算アル ゴリズムを組み込んだ土／水連成有限要素解析手法の 開発を行った. なお現在著者らの知る限り, 周知の地盤 材料モデルである Cam-clay モデルの場合の Consistent 弾塑性構成テンソルを用いた陰解法有限 要素法の解析は, Borja (1) $^{1)}$ 修正 Cam-clay モデルを 用いたものを報告しているが，それは土骨格の変形の みを考慮したもので, 土と水が連成している場合の陰解 法有限要素法解析の報告は無い.

\section{2. 土/水連成解析の定式化}

\section{1 支配方程式と境界条件}

地盤の変形挙動を考える際, 地盤を土粒子からなる骨格
（以下，土骨格と呼ぶ）（固体）と，その中に含まれてい る間隙水 (液体)，気泡（気体）の混合体として考えるの が一般的かつ合理的な手法であろう ${ }^{2)}$. しかし, 本論文の 目的は土質力学で通常用いられている有効応力の原理に 従う土/水連成数值解析の精度向上と計算時間の短縮に あるので, 間隙は水で完全飽和であり，有効応力を仮定す る 2 相混合体として取り扱う。.また，その間隙水は非㴼 性であると仮定する.

この簡単化された 2 相混合体に対する準静的な場合の 支配方程式は以下の6つの式で表される.

準静的なつりあい式:

$$
\operatorname{div} \boldsymbol{\sigma}=\mathbf{0},
$$

土骨格部分の弾塑性構成式：

$$
\dot{\boldsymbol{\sigma}}^{\prime}=\mathrm{C}^{e p} \dot{\boldsymbol{\varepsilon}},
$$

ひずみ変位関係式：

$$
\boldsymbol{\varepsilon}=(\nabla \boldsymbol{u})^{S},
$$

有効応力の原理 :

$$
\sigma=\sigma^{\prime}-p_{w} 1
$$

連続式：

$$
\operatorname{tr}(\dot{\varepsilon})+\operatorname{div}\left(v_{w}\right)=0,
$$


間隙水の流動則（ダルシー則）：

$$
\boldsymbol{v}_{w}=-\mathbf{K}_{\mathbf{p}} \operatorname{grad}\left(p_{w}\right) .
$$

ここで $\boldsymbol{\sigma}$ は全応カテンソル, $\boldsymbol{\sigma}^{\prime}$ は有効応カテンソル, $\mathbf{C}^{e p}$ は弾塑性構成テンソル， $p_{w}$ は間隙水圧，1 はクロネッカ 一のデルタ, $(\mathbf{1})_{i j}=\delta_{i j}, v_{w}$ は間隙水の流束ベクトル（土 骨格に対する相対速度)， $\mathbf{K}_{\mathrm{p}}$ は透水係数テンソルであり， 上付きの $S$ は（）内のテンソルの対称部分であることを 表している. また土骨格部分 (正確には混合体全体の変形 に対する境界条件），間隙水圧（全水頭）に対してそれぞ れ境界条件が課されており，土骨格に対する境界条件は

$$
\text { Neumann 境界: } \overline{\dot{t}}=\dot{\sigma} n \text { on } S_{\sigma},
$$

Dirichlet 境界 : $\overline{\dot{u}}=\dot{u} \quad$ on $S_{u}$.

である.ここで記号の上の一 (バー) は既知量であること 表しており， $S_{\sigma}$ は応力速度既知の境界， $S_{u}$ は変位速度既 知の境界であり, 土骨格部分に対する全境界を $S$ とすると

$$
S \supset S_{\sigma}, S \supset S_{u}, \phi=S_{\sigma} \cap S_{u},
$$

である. $\boldsymbol{n}$ は $S$ 上の単位法線ベクトルである. 間隙水圧 に対する境界条件は

Neumann 境界 : $\bar{q}=\boldsymbol{v}_{w} \cdot \boldsymbol{n}$ on $S_{q}$,

Dirichlet 境界 : $\bar{h}=h$ on $S_{h}$.

である. $q$ は単位時間あたりの流出入量, $h$ は全水頭を表 しており， $\gamma_{w}$ を間隙水の単位体積重量， $z$ を位置水頭と すると

$$
h=\frac{p_{w}}{\gamma_{w}}+z
$$

である. $S_{q}$ は流量既知の境界， $S_{h}$ は水頭既知の境界であ る. 間隙水厓に対する全境界を $S$ とすると

$$
S \supset S_{q}, S \supset S_{h}, \phi=S_{q} \cap S_{h},
$$

である.

\section{2 弱形式化と離散化}

以下のような試験関数を定義する.

$$
\delta \dot{\boldsymbol{u}}:=\left\{\delta \dot{\boldsymbol{u}} \mid \delta \dot{\varepsilon}=(\nabla \delta \dot{u})^{s}, \delta \dot{\boldsymbol{u}}=0 \text { on } S_{u}\right\},
$$

この試験関数をつりあい式（1）の速度型に掛け合わせ Gauss の発散定理と変形に対する力の境界条件 (7)，有 効応力の原理 (4) を用いるとつりあい式の速度型弱形式 が得られる.

$$
\int_{V}\left(\dot{\boldsymbol{\sigma}}^{\prime}-\dot{p}_{w} \mathbf{1}\right) \cdot \delta \dot{\boldsymbol{\varepsilon}} d v-\int_{S_{\sigma}} \overline{\dot{t}} \cdot \delta \dot{u} d s=0 .
$$

次にもう一方の未知量である間隙水压に関する試験関 数を定義する.

$$
\delta p_{w}:=\left\{\delta p_{w} \mid \delta p_{w}=0 \text { on } S_{h}\right\} .
$$

連続式（5）に掛け合わせ Gauss の発散定理と流量既知の 境界条件(10)を用いることにより，次のような連続式の弱 形式が得られる：

$$
\int_{V}\left\{\operatorname{tr}(\dot{\varepsilon}) \delta p_{w}-v_{w} \cdot \operatorname{grad}\left(\delta p_{w}\right)\right\} d v=-\int_{S_{q}} \bar{q} \delta p_{w} d s .(17)
$$

この $2 つ の$ 弱形式を有限要素法定式化するため空間的 離散化を行う，節点変位を $\boldsymbol{d}$ ，節点間隙水圧を $\boldsymbol{h}$ とする と

$$
\begin{aligned}
\dot{u} & =N \dot{d}, \\
\dot{\varepsilon} & =\nabla N \dot{d}=B \dot{d}, \\
\dot{\sigma}^{\prime} & =C^{e p} B \dot{d}, \\
\dot{p}_{w} & =n_{h}{ }^{\mathrm{T}} \dot{h}, \\
\operatorname{tr}(\dot{\varepsilon}) & =\mathbf{1}^{\mathrm{T}} \mathbf{B} \dot{d}=b_{v}{ }^{\mathrm{T}} \dot{d}, \\
p_{w} & =n_{h}{ }^{\mathrm{T}} h, \\
\operatorname{grad}\left(p_{w}\right) & =B_{h} h, \\
\boldsymbol{v}_{w} & =-\mathrm{K}_{\mathrm{p}} B_{h} h .
\end{aligned}
$$

ここで $N$ は変位に対する内挿関数であり, $n_{h}$ は間隙水圧 に対する内挿関数である. 詿験関数に対しても同様の離散 化が行えると仮定すると

$$
\begin{aligned}
\delta \dot{u} & =N \delta \dot{d}, \\
\delta \dot{\varepsilon} & =B \delta \dot{d}, \\
\delta p_{w} & =n_{h}{ }^{\mathrm{T}} \delta h, \\
\operatorname{grad}\left(\delta p_{w}\right) & =B_{h} \delta h,
\end{aligned}
$$

となる.なおここで空間的離散化を行った（18）式以降, 有限要素定式化の慣例に従い, 表記は変えていないが応力, ひずみはベクトル化, 構成テンソルはマトリクス化されて いることに注意する. したがって, 上付きの $T$ は転㯰行列 を意味する. (18)，(19)の関係を(15)，(17)に代入し整理す ると

$$
\begin{aligned}
& \mathbf{K} \dot{\boldsymbol{d}}-\mathbf{K}_{v}{ }^{\mathrm{T}} \dot{\boldsymbol{h}}=\dot{\mathbf{F}}^{\text {ext }}, \\
& \mathbf{K}_{v} \dot{\boldsymbol{d}}-\mathbf{K}_{h} \boldsymbol{h}=-\mathbf{Q},
\end{aligned}
$$

が得られる.ここで

$$
\begin{aligned}
\mathbf{K} & =\AA_{e=1}^{n e} \int_{V_{e}} \boldsymbol{B}^{T} \mathbf{C}^{e p} \boldsymbol{B} d v, \\
\mathbf{K}_{v}{ }^{\mathrm{T}} & =\AA_{e=1}^{n e} \int_{V_{e}} \boldsymbol{B}^{\mathrm{T}}\left(\mathbf{1} \otimes \boldsymbol{n}_{h}\right) d v \\
& =\AA_{e=1}^{n e} \int_{V_{e}}\left(\boldsymbol{b}_{v} \otimes \boldsymbol{n}_{h}\right) d v \\
\mathbf{K}_{v} & =\AA_{e=1}^{n e} \int_{V_{e}}\left(\boldsymbol{n}_{h} \otimes \boldsymbol{b}_{v}\right) d v,
\end{aligned}
$$




$$
\begin{aligned}
& \mathbf{K}_{h}=\overbrace{e=1}^{n e} \int_{\varphi_{e}} B_{h}{ }^{\mathrm{T}} \mathbf{K}_{\mathbf{p}} \boldsymbol{B}_{h} d v, \\
& \dot{\mathbf{F}}^{e x t}=\overbrace{e=1}^{n e} \int_{\sigma_{\sigma_{e}}} \boldsymbol{N}^{T} \overline{\dot{\boldsymbol{t}}} d s, \\
& \mathbf{Q}=\AA_{e=1}^{n e} \int_{S_{q_{e}}} \bar{q} \boldsymbol{n}_{\boldsymbol{h}} d s,
\end{aligned}
$$

であり，A は assembly operator と呼ばれ全要素数neの 数だけ重ね合わせる事を意味する.

式(20)，(21)の未知量には速度型の物理量と, 現在時の 物理量が混在しているので時間に関して離散化を行う. 時 間間隔 $\left[t_{n}, t_{n+1}\right]$ において物理量 $\psi$ が線形に変化するとす れば

$$
\begin{aligned}
& \psi=(1-\theta) \psi_{n}+\theta \psi_{n+1}, \\
& \dot{\psi}=\left(\psi_{n+1}-\psi_{n}\right) / \Delta t,
\end{aligned}
$$

と表せる. ここで，下付き添え字 $n, n+1$ はそれぞれ時 刻 $t_{n}, t_{n+1}$ での物理量であることを表しており，

$$
\begin{gathered}
\Delta t=t_{n+1}-t_{n}, \\
\theta=\left(t-t_{n}\right) / \Delta t, \\
t_{n}<t<t_{n+1}, \quad 0<\theta<1,
\end{gathered}
$$

である．よって（20），(21）式を書き直すと

$$
\begin{aligned}
& {\left[\begin{array}{cc}
\mathbf{K} & -\mathbf{K}_{v}{ }^{\mathrm{T}} \\
\mathbf{K}_{v} & \theta \Delta t \mathbf{K}_{h}
\end{array}\right]\left\{\begin{array}{l}
\Delta d \\
\Delta h
\end{array}\right\}} \\
& =\left\{\begin{array}{l}
\Delta \mathbf{F}^{e x t} \\
-\Delta t \mathbf{K}_{h} h_{n}-\Delta t\left[(1-\theta) \mathbf{Q}_{n}+\theta \mathbf{Q}_{n+1}\right]
\end{array}\right\}
\end{aligned}
$$

となる.ここで

$$
\begin{aligned}
\Delta d & =d_{n+1}-d_{n}, \\
\Delta h & =h_{n+1}-h_{n},
\end{aligned}
$$

である。

2.3 Newton Raphson 法に整合する土水連成解析の定式化 前節の土/水連成解析定式化は時間間隔 $\left[t_{n}, t_{n+1}\right]$ におい て, 土骨格部分の弾塑性計算に関しては式 (31) 左辺の剛 性マトリクス内の応力に既知の応力を用いた陽解法近似， 間隙水圧の時間的離散化に関しては陰解法近似 $(\theta=1$ と した時）をしているものが多い. 近年, 弾塑性計算アルゴ リズムに関して Elastic-plastic operator split の概念に基 づく General return mapping algorithmsにより, 精度良 く降伏曲面上にのる応力を求め, 全体の非線形連立方程式 を Newton Raphson 法に整合するよう Consistent 接線剛 性テンソルを用い, 求解の過程において誤差が 2 次収束す ることが保証された陰解法弾塑性計算アルゴリズムが提 案されている3) . 本報告ではその方法を応用し, 陰解法弾 塑性計算アルゴリズムを用いた土/水連成解析を行い，そ
の解析精度, 計算時間の検証を行った.

土骨格部分を弾塑性体とする土/水連成有限要素法定 式化は最終的には節点における離散化された変位 $\boldsymbol{d}$ と間 隙水圧 $\boldsymbol{h}$ を未知とする非線形連立方程式に帰着される。 そ の連立方程式を次式のように表す：

$$
\begin{aligned}
& \mathbf{F}^{e x t}-\mathbf{F}^{\text {int }}=\mathbf{0}, \\
& \mathbf{G}^{e x t}-\mathbf{G}^{\text {int }}=\mathbf{0} .
\end{aligned}
$$

ここで式（33）は混合体のつりあい式(1）(注 : 速度型つ り合い式ではない)の弱形式の離散化による式であり, 式

（34）は連続式(5)の離散化による式である. 上付き ext は 外力ベクトルを表し，上付きint は内力ベクトルを表す. 具体的にそれらを記すと次式のようになる：

$$
\mathbf{F}^{\mathrm{int}}\left(\boldsymbol{\sigma}_{n+1}\right)=\AA_{e=1}^{n e} \int_{r e} \boldsymbol{B}^{\mathrm{T}} \boldsymbol{\sigma}_{n+1} d v,
$$

$$
\begin{aligned}
& \mathbf{G}^{\text {int }}\left(\operatorname{tr}\left[\varepsilon_{n+1}\right], \boldsymbol{v}_{w, n+1}\right) \\
& =\AA_{e=1}^{n e} \int\left[n_{i e}\left\{\operatorname{tr}\left[\varepsilon_{n+1}\right]-\operatorname{tr}\left[\varepsilon_{n}\right]\right\}-\Delta t B_{h}{ }^{\mathrm{T}} \boldsymbol{v}_{w, n+1}\right] d v, \\
& \mathbf{F}_{n+1}^{e x t}=\AA_{e=1}^{n e} \int_{s_{e x}} \boldsymbol{N}^{T} \bar{t}_{n+1} d s, \\
& \mathbf{G}_{n+1}^{e x t}=\AA_{e=1}^{n e} \int_{s_{q_{e}}} \Delta t \bar{q}_{n+1} \boldsymbol{n}_{\boldsymbol{h}} d s .
\end{aligned}
$$

次に，離散化された式（33），（34）の変位と間隙水圧 の非線形連立方程式に Newton Raphson 法を適用するた めに Taylor 展開を行い，節点変位増分 $\Delta \boldsymbol{d}_{n+1}=\boldsymbol{d}_{n+1}^{(k+1)}-\boldsymbol{d}_{n+1}^{(k)}$ および節点間隙水圧増分 $\Delta \boldsymbol{h}_{n+1}=\boldsymbol{h}_{n+1}^{(k+1)}-\boldsymbol{h}_{n+1}^{(k)}$ に関する線形近似化を行う.ここで, 各物理量の下付添え字 $n$ は荷重ステップ数, 上付き添え字 (k) は各増分ステップ内のイタレーション回数を表して いる. 式（35）を $\Delta \boldsymbol{d}$ と $\Delta \boldsymbol{h}$ の一次の項まで Taylor 展開 すると :

$$
\begin{aligned}
& \mathbf{F}^{\text {int }}\left(\boldsymbol{\sigma}_{n+1}^{(k+1)}\right) \\
= & \hat{\mathbf{F}}^{\text {int }}\left(\boldsymbol{d}_{n+1}^{(k+1)}, \boldsymbol{h}_{n+1}^{(k+1)}\right), \\
\approx & \mathbf{F}^{\text {int }}\left(\boldsymbol{\sigma}_{n+1}^{(k)}\right)+\frac{\partial \mathbf{F}^{\text {int }}\left(\boldsymbol{\sigma}_{n+1}^{(k)}\right)}{\partial \boldsymbol{d}_{n+1}^{(k)}} \Delta \boldsymbol{d}_{n+1}-\frac{\partial \mathbf{F}^{\text {int }}\left(\boldsymbol{\sigma}_{n+1}^{(k)}\right)}{\partial \boldsymbol{h}_{n+1}^{(k)}} \Delta \boldsymbol{h}_{n+1},
\end{aligned}
$$

となる.

上式，右辺第 2 項および第 3 項は有効応力の原理(4) と, assembly operator $A$ が線形であることに注意すれば式

（35）に微分の chain rule を用いて以下のようになる：

$$
\begin{aligned}
& \frac{\partial \mathbf{F}^{\mathrm{int}}\left(\boldsymbol{\sigma}_{n+1}^{(k)}\right)}{\partial \boldsymbol{d}_{n+1}^{(k)}} \Delta \boldsymbol{d}_{n+1} \\
= & \AA_{e=1}^{n e} \int_{V_{e}} \boldsymbol{B}^{\mathrm{T}} \frac{\partial \boldsymbol{\sigma}_{n+1}^{(k)}}{\partial \boldsymbol{\sigma}_{n+1}^{\prime(k)}} \frac{\partial \boldsymbol{\sigma}_{n+1}^{\prime(k)}}{\partial \boldsymbol{\varepsilon}_{n+1}^{(k)}} \frac{\partial \boldsymbol{\varepsilon}_{n+1}^{(k)}}{\partial \boldsymbol{d}_{n+1}^{(k)}} d v \Delta \boldsymbol{d}_{n+1},
\end{aligned}
$$




$$
\begin{aligned}
& =\AA_{e=1}^{n e}\left[\int_{r e} \boldsymbol{B}^{\mathrm{T}} \overline{\mathbf{C}}^{e \rho_{n+1}^{(k)}} \boldsymbol{B} d v\right] \Delta \boldsymbol{d}_{n+1}, \\
& =\AA_{e=1}^{n e} \mathbf{K}_{e n+1}^{(k)} \Delta d_{n+1}, \\
& =\mathbf{K}_{n+1}^{(k)} \Delta \boldsymbol{d}_{n+1} . \\
& \frac{\partial \mathbf{F}^{\text {int }}\left(\boldsymbol{\sigma}_{n+1}^{(k)}\right)}{\partial \boldsymbol{h}_{n+1}^{(k)}} \Delta \boldsymbol{h}_{n+1} \\
& =\AA_{e=1}^{n e} \int_{V e} \boldsymbol{B}^{\mathrm{T}} \frac{\partial \boldsymbol{\sigma}_{n+1}^{(k)}}{\partial \boldsymbol{\sigma}_{n+1}^{\prime(k)}} \frac{\partial \boldsymbol{\sigma}_{n+1}^{\prime(k)}}{\partial p_{w, n+1}^{(k)}} \otimes \frac{\partial p_{w, n+1}^{(k)}}{\partial \boldsymbol{h}_{n+1}^{(k)}} d v \Delta \boldsymbol{h}_{n+1}, \\
& =\mathrm{A}_{e=1}^{n e}\left[\int_{V e} B^{\mathrm{T}}\left(1 \otimes n_{h}\right) d v\right] \Delta \boldsymbol{h}_{n+1}, \\
& =\AA_{e=1}^{n e}\left[\int_{r e}\left(\boldsymbol{b}_{v} \otimes \boldsymbol{n}_{h}\right) d v\right] \Delta \boldsymbol{h}_{n+1}, \\
& =\AA_{e=1}^{n e} \mathbf{K}_{v, e}^{\mathrm{T}} \Delta \boldsymbol{h}_{n+1} \text {, } \\
& =\mathbf{K}_{v}^{\mathrm{T}} \Delta \boldsymbol{h}_{n+1} \text {. }
\end{aligned}
$$

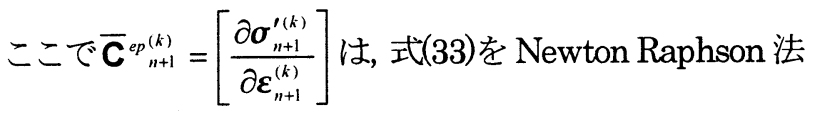

て解く場合，それに整合した Consistent 弾塑性構成テン ソルであり, 一次元の場合を除き,一般には式(2)内の (Continuum) 弾塑性構成テンソル $\mathbf{C}^{e p}$ とは一致しない. 結局, 式(40), (41)を式(39)に代入すると

$$
\begin{aligned}
& \mathbf{F}^{\mathrm{i} \text { int }}\left(\boldsymbol{\sigma}_{n+1}^{(k+1)}\right) \\
\approx & \mathbf{F}^{\mathrm{int}}\left(\boldsymbol{\sigma}_{n+1}^{(k)}\right)+\mathbf{K}_{n+1}^{(k)} \Delta \boldsymbol{d}_{n+1}-\mathbf{K}_{v}^{\mathrm{T}} \Delta \boldsymbol{h}_{n+1}
\end{aligned}
$$

となる。

同様に式（36）を Taylor 展開し，微分の chain rule を用いれば, 式(36)は

$$
\begin{aligned}
& \mathbf{G}^{\text {int }}\left(\operatorname{tr}\left[\boldsymbol{\varepsilon}_{n+1}^{(k+1)}\right], \boldsymbol{v}_{w, n+1}^{(k+1)}\right) \\
& =\hat{\mathbf{G}}^{\text {int }}\left(\boldsymbol{d}_{n+1}^{(k+1)}, \boldsymbol{h}_{n+1}^{(k+1)}\right) \\
& \approx \mathbf{G}^{\text {int }}\left(\operatorname{tr}\left[\boldsymbol{\varepsilon}_{n+1}^{(k)}\right], \boldsymbol{v}_{w, n+1}^{(k)}\right)+\mathbf{K}_{v} \Delta \boldsymbol{d}_{n+1}+\Delta t \mathbf{K}_{h} \Delta \boldsymbol{h}_{n+1}
\end{aligned}
$$

となる、第 $(k)$ イタレーション終了段階において式 (33)，(34)に残差力が生じ，第 $(k+1)$ イタレーション で残差がゼロとなるように考えると，

$$
\begin{aligned}
& \mathbf{F}^{\text {ext }}-\left\{\mathbf{F}^{\text {int }}\left(\boldsymbol{\sigma}_{n+1}^{(k)}\right)\right. \\
& \left.+\frac{\partial \mathbf{F}_{n+1}^{\text {int }(k)}}{\partial \boldsymbol{d}_{n+1}^{(k)}} \Delta \boldsymbol{d}_{n+1}-\frac{\partial \mathbf{F}_{n+1}^{\text {in }(k)}}{\partial \boldsymbol{h}_{n+1}^{(k)}} \Delta \boldsymbol{h}_{n+1}\right\}=\mathbf{0}, \\
& \mathbf{G}^{\text {ext }}-\left\{\mathbf{G}_{n+1}^{\mathrm{in}(k)}\right. \\
& \left.+\frac{\partial \mathbf{G}_{n+1}^{\text {int }(k)}}{\partial \boldsymbol{d}_{n+1}^{(k)}} \Delta \boldsymbol{d}_{n+1}+\frac{\partial \mathbf{G}_{n+1}^{\text {in }(k)}}{\partial \boldsymbol{h}_{n+1}^{(k)}} \Delta \boldsymbol{h}_{n+1}\right\}=\mathbf{0},
\end{aligned}
$$

ると

$$
\left[\begin{array}{cc}
\frac{\partial \mathbf{F}_{n+1}^{\mathrm{int}(k)}}{\partial \boldsymbol{d}_{n+1}^{(k)}} & -\frac{\partial \mathbf{F}_{n+1}^{\mathrm{in}(k)}}{\partial \boldsymbol{h}_{n+1}^{(k)}} \\
\frac{\partial \mathbf{G}_{n+1}^{\text {int }(k)}}{\partial \boldsymbol{d}_{n+1}^{(k)}} & \frac{\partial \mathbf{G}_{n+1}^{\text {int }(k)}}{\partial \boldsymbol{h}_{n+1}^{(k)}}
\end{array}\right]\left\{\begin{array}{l}
\Delta \boldsymbol{d}_{n+1} \\
\Delta \boldsymbol{h}_{n+1}
\end{array}\right\}=-\left\{\begin{array}{c}
\mathbf{F}_{n+1}^{\mathrm{int}(k)}-\mathbf{F}_{n+1}^{e x t} \\
\mathbf{G}_{n+1}^{\text {int }(k)}-\mathbf{G}_{n+1}^{\text {ext }}
\end{array}\right\}(46)
$$

となる. 以上から上式(46)は離散化された $\boldsymbol{d}$ と $\boldsymbol{h}$ の非線形 連立方程式, 式 (33) と式 (34) を解く Newton Raphson 法に整合していることが分かる.

3. 陰解法弾塑性計算アルゴリズム

3.1 Cam - clay モデル

Cam-clay の降伏関数は以下のように与えられる.

$$
f\left(p, q, p_{c}\right)=q+\mathrm{M} p \ln \left(\frac{p}{p_{c}}\right)=0
$$

ここで平均応力 $p=-\frac{1}{3} \operatorname{tr}\left(\boldsymbol{\sigma}^{\prime}\right)$ であり, 一般化偏差応力 $q=\sqrt{\frac{3}{2}}\|S\|$, 偏差応力 $S=\sigma^{\prime}-\frac{1}{3} \operatorname{tr}\left(\sigma^{\prime}\right) 1$ である. 応力の 右上のダッシュは有効応力であることを表している. 忘力, ひずみ等は引張り正であり, 平均応力, 体積ひずみ等は土 質力学の慣例に従い圧縮を正としている. $\mathrm{M}$ は限界応力 比, $p_{c}$ は先行圧密応力である. 降伏関数 $f$ の $p, q, p_{c}$ での微分を求めると :

$$
\begin{aligned}
& \frac{\partial f}{\partial p}=\mathrm{M}\left[1+\ln \left(\frac{p}{p_{c}}\right)\right], \\
& \frac{\partial f}{\partial q}=1, \\
& \frac{\partial f}{\partial p_{c}}=-\mathrm{M} \frac{p}{p_{c}}
\end{aligned}
$$

である.

関連流れ則を仮定すると塑性ひずみ速度テンソルは次 式で与えられ：

$$
\dot{\boldsymbol{\varepsilon}}^{p}=\dot{\phi} \frac{\partial f}{\partial \sigma^{\prime}},
$$

ここで் はコンシステンシーパラメータである.

$$
\frac{\partial f}{\partial \sigma^{\prime}}=\frac{\partial f}{\partial p} \frac{\partial p}{\partial \sigma^{\prime}}+\frac{\partial f}{\partial q} \frac{\partial q}{\partial \sigma^{\prime}}=-\frac{1}{3}\left(\frac{\partial f}{\partial p}\right) 1+\sqrt{\frac{3}{2}}\left(\frac{\partial f}{\partial q}\right) \hat{n}
$$

であり, ここで $\hat{n}=S /\|S\|$ である.

また硬化則は

$$
\dot{p}_{c}=\frac{p_{c}}{\mathrm{M} D} \dot{\varepsilon}_{v}^{p},
$$

で与えられ， $D$ はダイレイタンシー倸数であり， $\lambda$ を圧 
縮指数, $\kappa$ を膨閏指数, $e$ を間隙比とすると

$$
D=\frac{\lambda-\kappa}{\mathrm{M}(1+e)},
$$

で与えられる.

応力速度が弾性構成テンソルと弾性ひずみ速度で表せ ること，流れ則 $(49)$ ，硬化則（51）， $\dot{\phi}>0$ の際の consistency 条件 :

$$
\dot{f}\left(\boldsymbol{\sigma}^{\prime}, p_{c}\right)=\frac{\partial f}{\partial \boldsymbol{\sigma}^{\prime}} \cdot \dot{\boldsymbol{\sigma}}^{\prime}+\frac{\partial f}{\partial p_{c}} \dot{p}_{c}=0
$$

を用いることにより

$$
\dot{\boldsymbol{\sigma}}^{\prime}=\left[\mathbf{C}-\frac{\mathbf{C} \frac{\partial f}{\partial \boldsymbol{\sigma}^{\prime}} \otimes \frac{\partial f}{\partial \boldsymbol{\sigma}^{\prime}} \mathbf{C}}{\frac{\partial f}{\partial \boldsymbol{\sigma}^{\prime}} \cdot \mathbf{C} \frac{\partial f}{\partial \boldsymbol{\sigma}^{\prime}}-\frac{p_{c}}{M D} \frac{\partial f}{\partial p_{c}} \frac{\partial f}{\partial p}}\right] \dot{\boldsymbol{\varepsilon}}
$$

が得られる.ここでC は弾性構成テンソルであり, Cam-clay モデルの場合

$$
\mathrm{C}=\widetilde{\mathrm{K}} 1 \otimes 1+2 \widetilde{\mathrm{G}}\left(I-\frac{1}{3} 1 \otimes 1\right),
$$

と表される.ここで1 $\otimes 1$ とI はそれぞれ 4 階の恒等テン ソルであり, $(\mathbf{1} \otimes \mathbf{1})_{i j k l}=\delta_{i j} \delta_{k l},(\mathbf{I})_{i j k l}=\frac{1}{2}\left(\delta_{i k} \delta_{j l}+\delta_{i l} \delta_{j k}\right)$ で ある. また係数 $\widetilde{\mathrm{K}}=(1+e) p / \kappa, \widetilde{\mathrm{G}}=3 \widetilde{\mathrm{K}}(1-2 v) / 2(1+v)$ であり, $v$ はポアソン比である.

式(48)の関係を代入し，整理することにより (Continuum) 弾塑性構成テンソル $\mathbf{C}^{e p}$ を得ることがで きる :

$$
\mathrm{C}^{e p}=2 \widetilde{\mathrm{G}} I+\mathrm{c}_{1}(1 \otimes 1)+\mathrm{c}_{2}(\hat{n} \otimes 1+1 \otimes \hat{n})+\mathrm{c}_{3}(\hat{n} \otimes \hat{n}) .
$$

ここで

である.

$$
\begin{aligned}
c_{1} & =\frac{\widetilde{\mathrm{K}}}{\chi}\left\{\frac{p}{D} \mathrm{M}\left[1+\ln \left(\frac{p}{p_{c}}\right)\right]+3 \widetilde{\mathrm{G}}\right\}-\frac{2}{3} \widetilde{\mathrm{G}}, \\
c_{2} & =\frac{\widetilde{\mathrm{K}}}{\chi} \sqrt{6} \widetilde{\mathrm{G}} \mathrm{M}\left[1+\ln \left(\frac{p}{p_{c}}\right)\right], \\
c_{3} & =-\frac{6}{\chi} \widetilde{\mathrm{G}}^{2}, \\
\chi & =\widetilde{\mathrm{K}} \mathrm{M}^{2}\left[1+\ln \left(\frac{p}{p_{c}}\right)\right]^{2} \\
& +\frac{p}{D} \mathrm{M}\left[1+\ln \left(\frac{p}{p_{c}}\right)\right]+3 \widetilde{\mathrm{G}},
\end{aligned}
$$

\subsection{Trial elastic state}

時間間隔 $\left[t_{n}, t_{n+1}\right]$ の増分弾塑性初期值境界値問題を考 え, 時刻 $t_{n}$ の時の $\left\{\boldsymbol{\varepsilon}_{n}, \boldsymbol{\sigma}_{n}^{\prime},\left(p_{c}\right)_{n}\right\}$ が既知であると仮定する.
今, 与えられた $\varepsilon_{n+1}^{(k)} に$ 対して trial elastic state は次式で与 えられる：

$$
\begin{aligned}
\Delta \varepsilon_{n+1}^{(k)} & :=\boldsymbol{\varepsilon}_{n+1}^{(k)}-\boldsymbol{\varepsilon}_{n}, \\
\boldsymbol{\sigma}_{n+1}^{\prime \prime \text { rial }} & :=\boldsymbol{\sigma}_{n}^{\prime}+\mathbf{C} \Delta \boldsymbol{\varepsilon}_{n+1}^{(k)}, \\
\left(p_{c}\right)_{n+1}^{\text {rial }} & :=\left(p_{c}\right)_{n} .
\end{aligned}
$$

上式より試行平均応力, 試行一般化偏差応力, 試行偏差 応力は

$$
\begin{aligned}
& p_{n+1}^{\text {trial }}=-\frac{1}{3} \operatorname{tr}\left(\boldsymbol{\sigma}_{n+1}^{\prime \text { trial }}\right), \\
& q_{n+1}^{\text {trial }}=\sqrt{\frac{3}{2}}\left\|S_{n+1}^{\text {trial }}\right\|, \\
& S_{n+1}^{\text {trial }}=\boldsymbol{\sigma}_{n+1}^{\prime \text { trial }}-\frac{1}{3} \operatorname{tr}\left(\boldsymbol{\sigma}_{n+1}^{\prime \text { trial }}\right) \boldsymbol{1},
\end{aligned}
$$

と表される.

負荷除荷判定は，離散化 Kuhn-Tucker 条件により

$$
f_{n+1}^{\text {trial }}\left\{\begin{array}{l}
\leq 0 \Rightarrow \text { elastic step } \quad \Delta \phi=0 \\
>0 \Rightarrow \text { plastic step } \quad \Delta \phi>0 .
\end{array}\right.
$$

で行われ,ここで

$$
f_{n+1}^{\text {trial }}=q_{n+1}^{\text {trial }}+\mathrm{M} p_{n+1}^{\text {trial }} \ln \left(\frac{p_{n+1}^{\text {trial }}}{\left(p_{c}\right)_{n}}\right)=0,
$$

である.

\subsection{Return mapping algorithm : closest point projection method}

(60)の負荷除荷判定において $\left[t_{n}, t_{n+1}\right]$ の現ステップが塑 性ステップであると判断された際, 単に陽解法近似を行っ た計算アルゴリズムで増分解析を行うと，一般に求まった 応力等が降伏曲面上にないので降伏曲面上に応力を引き 戻す必要がある.これを Return mapping algorithms と 呼ぶが, Simo らは Algorithmic tangential moduli を用い た General return mapping algorithm を提案している4). 地盤材料においての Consistent 弾塑性構成テンソルを用 いた陰解法有限要素法の解析は，Borja $ら^{1)}$ が修正 Cam-clay モデルを用いたものを報告している. しかし， 彼らの論文では修正 Cam-clay モデルを用いた，土骨格の 変形のみを考慮したものに限定されている. そこで本報告 では彼らの方法を応用し，Cam-clay モデルを用いた土と 水が連成している場合の陰解法有限要素法を提案する.

流れ則(49), 硬化則(51)の有限時間積分により, 次式が 得られる：

$$
\Delta \varepsilon^{p}=\Delta \phi \frac{\partial f}{\partial \sigma^{\prime}}
$$




$$
\begin{aligned}
& \Delta \varepsilon_{v}^{p}=\Delta \phi \frac{\partial f}{\partial p}, \\
& \left(p_{c}\right)_{n+1}=\left(p_{c}\right)_{n} \exp \left(\frac{\Delta \frac{\Delta p}{M D}}{M D}\right),
\end{aligned}
$$

Return mapping 応力 tensor を次式のように表す：

$$
\boldsymbol{\sigma}_{n+1}^{\prime(k)}=\boldsymbol{\sigma}_{n+1}^{\prime \prime r i a l}-\mathbf{C} \Delta \varepsilon^{p}
$$

この $\boldsymbol{\sigma}_{n+1}^{\prime(k)}$ の平均応力部分を考えると

$$
p:=p_{n+1}^{(k)}=p_{n+1}^{\text {trial }}-\widetilde{\mathrm{K}} \Delta \varepsilon_{v}^{p},
$$

偏差部分は

$$
q:=q_{n+1}^{(k)}=q_{n+1}^{\text {trial }}-3 \widetilde{\mathrm{G}} \Delta \gamma^{p},
$$

となる. ここで $q_{n+1}^{\text {trial }}=\sqrt{\frac{3}{2}}\left\|S_{n+1}^{\text {trial }}\right\|, \Delta \gamma^{p}=\sqrt{\frac{2}{3}}\left\|\Delta \gamma^{p}\right\|$, $\Delta \gamma^{p}=\Delta \varepsilon^{p}+\frac{1}{3} \Delta \varepsilon_{v}^{p} 1$ である. (66),(67),(64)に(48),(63)の関 係を代入すると：

$$
\begin{aligned}
& p=p_{n+1}^{\text {trial }}-\Delta \phi \widetilde{\mathrm{K}} \mathrm{M}\left[1+\ln \left(\frac{p}{p_{c}}\right)\right], \\
& q=q_{n+1}^{\text {trial }}-3 \widetilde{\mathrm{G}} \Delta \phi, \\
& p_{c}:=\left(p_{c}\right)_{n+1}=\left(p_{c}\right)_{n}\left(\frac{p}{p_{c}}\right)^{\frac{\Delta \phi}{D}} \exp \left(\frac{\Delta \phi}{D}\right),
\end{aligned}
$$

となり, コンシステンシー条件(47)の $f=0$ とあわせると $p, q, p_{c}, \Delta \phi$ に関寸る非線形連立方程式となってい ることが分かる.

\subsection{Scalar consistency parameter $の$ 決定}

式(68)，(69)，(70)内のパラメータ $\Delta \phi$ は consistency 要求(47)を満たすように決定されなければならない．この 根 $\Delta \psi$ はスカラ一関数 $f$ にNewton Raphson 法走適用寸 ることにより求めることができるが, その際の初期値とし ては $p=p_{n+1}^{\text {trial }}, q=q_{n+1}^{\text {trial }}, p_{c}=\left(p_{c}\right)_{n}, \Delta \phi=0$ を用いる. $f$ の $\Delta \phi$ による偏微分 $f^{\prime}$ は, chain rule を用いると

$$
f^{\prime}(\Delta \phi)=\frac{\partial f}{\partial p} \frac{\partial p}{\partial(\Delta \phi)}+\frac{\partial f}{\partial q} \frac{\partial q}{\partial(\Delta \phi)}+\frac{\partial f}{\partial p_{c}} \frac{\partial p_{c}}{\partial(\Delta \phi)}
$$

となる. ここで $\partial f / \partial p, \partial f / \partial q, \partial f / \partial p_{c}$ は式 (48) で与 えられている. また式 (68)，（69），（70）を微分し， 陰的に解くことにより

$$
\begin{aligned}
& \frac{\partial p}{\partial(\Delta \phi)}=-\frac{\widetilde{\mathrm{K}} \mathrm{M} D\left[1+\ln \left(\frac{p}{p_{c}}\right)\right]}{D+\widetilde{\mathrm{K}} \mathrm{M} \Delta \phi / p+\Delta \phi}, \\
& \frac{\partial q}{\partial(\Delta \phi)}=-3 \widetilde{\mathrm{G}},
\end{aligned}
$$

1. 初期化 $k=0, \Delta \phi^{(k)}=0$.

2. $f^{(k)}=f\left(\Delta \phi^{(k)}\right)$ の計算.

2.1. 初期化 $j=0, p^{(j)}=p_{n+1}^{\text {trial }}$.

$2.2 g^{(j)}=g\left(p^{(j)}\right)$ の計算.

2.3 if $\left|g^{(j)}\right|<g_{t o l}$, goto 2.6 ; else,

$2.4 p^{(j+1)}=p^{(j)}-\frac{g^{(j)}}{g^{\prime}\left(p^{(j)}\right)}$.

$2.5 j \leftarrow j+1$, goto 2.2 .

$2.6 f^{(k)}=f\left(\Delta \phi^{(k)}, p^{(k)}, q^{(k)}, p_{c}^{(k)}\right)$ を 計算し, return.

3. if $\left|f^{(k)}\right|<f_{t o l}$, exit; else,

4. $\Delta \phi^{(k+1)}=\Delta \phi^{(k)}-\frac{f^{(k)}}{f^{\prime}\left(\Delta \phi^{(k)}\right)}$.

5. $k \leftarrow k+1$, goto 2 .

図一 $1 f=0, g=0$ とする根 $p, q, p_{c}, \Delta \phi$ を求め る Newton Raphson algorithm.

$$
\frac{\partial p_{c}}{\partial(\Delta \phi)}=-\frac{p_{c}\left[1+\ln \left(\frac{p}{p_{c}}\right)\right]}{D+\widetilde{K} M \Delta \phi / p+\Delta \phi}
$$

となる. ここで, 変数 $p, p_{c}$ は式 (68)，（70）と連成 しているため, 関数 $f\left(\Delta \phi^{(k)}\right)$ は陽には求まらない，そこ で $p$ と $p_{c}$ は反復的に解く.

式（70）を変形し，再表記すると

$$
p_{c}=\left[\left(p_{c}\right)_{n} p^{\frac{\Delta \phi^{(k)}}{D}} \exp \left(\frac{\Delta \phi^{(k)}}{D}\right)\right]^{\frac{D}{D+\Delta \phi^{(k)}}},
$$

となり,これを式 (68)に代入することにより次式を得る：

$$
\begin{aligned}
& g(p):=p_{n+1}^{\text {trial }} \\
& \quad+\Delta \phi^{(k)} \widetilde{\mathrm{K}} M \frac{D}{D+\Delta \phi^{(k)}}\left[\ln \left(p_{c}\right)_{n}-(1+\ln p)\right]-p=0,
\end{aligned}
$$

この式の根 $p=p_{n+1}^{(k)}$ は, Newton Raphson 法を用いる ことにより, 反復的に求められる. $g$ の $p$ による偏微分 $g^{\prime}$ は

$$
g^{\prime}(p)=-\left(1+\Delta \phi^{(k)} \widetilde{\mathrm{K}} \mathrm{M} \frac{D}{D+\Delta \phi^{(k)}} \frac{1}{p}\right)
$$


である.

この $p, q, p_{c}, \Delta \phi$ を求める 2 重の Newton Raphson 法のアルゴリズムを図一 1 に示寸。

\subsection{Consistent 弾塑性構成テンソル}

ひずみテンソル増分 $\varepsilon_{n+1}^{(k)}-\varepsilon_{n}$ を考慮した増分応答関数 は次式のように表される :

$$
\boldsymbol{\sigma}_{n+1}^{\prime(k)}=\frac{1}{3} \operatorname{tr}\left(\boldsymbol{\sigma}_{n+1}^{\prime(k)}\right) \mathbf{1}+\left\|\boldsymbol{S}_{n+1}^{(k)}\right\| \hat{\boldsymbol{n}}=-p \mathbf{1}+\sqrt{\frac{2}{3}} q \hat{\boldsymbol{n}} \cdot(78)
$$

Consistent 弾塑性構成テンソルは, 式（78）の直接的な 偏微分により次式のように得られる：

$$
\begin{aligned}
\overline{\mathbf{C}}^{e p}{ }_{n+1}^{(k)} & =\frac{\partial \boldsymbol{\sigma}_{n+1}^{(k)}}{\partial \boldsymbol{\varepsilon}_{n+1}^{(k)}} \\
& =-\mathbf{1} \otimes \frac{\partial p}{\partial \boldsymbol{\varepsilon}_{n+1}^{(k)}}+\sqrt{\frac{2}{3}} q \frac{\partial \hat{\boldsymbol{n}}}{\partial \boldsymbol{\varepsilon}_{n+1}^{(k)}}+\sqrt{\frac{2}{3}} \hat{\boldsymbol{n}} \otimes \frac{\partial q}{\partial \boldsymbol{\varepsilon}_{n+1}^{(k)}} .
\end{aligned}
$$

ここで $\frac{\partial \boldsymbol{\sigma}_{n+1}^{\prime(k)}}{\partial p}=-\mathbf{1}, \frac{\partial \boldsymbol{\sigma}_{n+1}^{\prime(k)}}{\partial \hat{\boldsymbol{n}}}=\sqrt{\frac{2}{3}} q \boldsymbol{I}, \frac{\partial \boldsymbol{\sigma}_{n+1}^{\prime(k)}}{\partial q}=\sqrt{\frac{2}{3}} \hat{\boldsymbol{n}}$ を 用いた。

式（79）内の各偏微分量は式（68），(70）を用いて陰 的に得ることができる. $p$ の $\boldsymbol{\varepsilon}_{n+1}^{(k)}$ による微分は：

$$
\frac{\partial p}{\partial \varepsilon_{n+1}^{(k)}}=a_{1} \mathbf{1}+a_{2} \frac{\partial(\Delta \phi)}{\partial \boldsymbol{\varepsilon}_{n+1}^{(k)}},
$$

となり,ここで

$$
\begin{aligned}
& a_{1}=-\widetilde{\mathrm{K}} p(D+\Delta \phi) / a, \\
& a_{2}=-\widetilde{\mathrm{K}} \mathrm{M} D p\left[1+\ln \left(\frac{p}{p_{c}}\right)\right] / a, \\
& a=D p+\Delta \phi(p+\widetilde{\mathrm{K}} \mathrm{M} D),
\end{aligned}
$$

である. また $p_{c}$ の $\boldsymbol{\varepsilon}_{n+1}^{(k)}$ による微分は：

$$
\frac{\partial p_{c}}{\partial \varepsilon_{n+1}^{(k)}}=a_{3} 1+a_{4} \frac{\partial(\Delta \phi)}{\partial \varepsilon_{n+1}^{(k)}},
$$

となり,ここで

$$
\begin{aligned}
& a_{3}=-\widetilde{\mathrm{K}} p_{\mathrm{c}} \Delta \phi / a, \\
& a_{4}=p_{c} p\left[1+\ln \left(\frac{p}{p_{c}}\right)\right] / a,
\end{aligned}
$$

である. $q$ の $\boldsymbol{\varepsilon}_{n+1}^{(k)}$ による微分は：

$$
\frac{\partial q}{\partial \varepsilon_{n+1}^{(k)}}=\sqrt{6} \widetilde{\mathrm{G}} \hat{n}-3 \widetilde{\mathrm{G}} \frac{\partial(\Delta \phi)}{\partial \varepsilon_{n+1}^{(k)}},
$$

となる. 次に consistenscy の要求を課すことにより
$\partial(\Delta \phi) / \partial \varepsilon_{n+1}^{(k)}$ を得ることができる。すなおち $f=f\left(\Delta \phi\left(\varepsilon_{n+1}^{(k)}\right)\right)$ を $\varepsilon_{n+1}^{(k)}$ で偏微分した結果 :

$$
\frac{\partial f}{\partial \varepsilon_{n+1}^{(k)}}=\frac{\partial f}{\partial p} \frac{\partial p}{\partial \varepsilon_{n+1}^{(k)}}+\frac{\partial f}{\partial q} \frac{\partial q}{\partial \varepsilon_{n+1}^{(k)}}+\frac{\partial f}{\partial p_{c}} \frac{\partial p_{c}}{\partial \varepsilon_{n+1}^{(k)}} \equiv 0
$$

に式（80），(82），(84）を代入することにより

$$
\frac{\partial(\Delta \phi)}{\partial \varepsilon_{n+1}^{(k)}}=b_{1} \mathbf{1}+b_{2} \hat{\boldsymbol{n}}
$$

を得る.ここで

$$
\begin{aligned}
& b_{1}=\mathrm{M}\left\{a_{3} \frac{p}{p_{c}}-a_{1}\left[1+\ln \left(\frac{p}{p_{c}}\right)\right]\right\} / b, \\
& b_{2}=-\sqrt{6} \widetilde{\mathrm{G}} / b, \\
& b=-\mathrm{M}\left\{a_{4} \frac{p}{p_{c}}-a_{2}\left[1+\ln \left(\frac{p}{p_{c}}\right)\right]\right\}-3 \widetilde{\mathrm{G}},
\end{aligned}
$$

である.

式（86）を（80），（82），（84）に代入することに よって次の関係式を得る：

$$
\begin{aligned}
\frac{\partial p}{\partial \boldsymbol{\varepsilon}_{n+1}^{(k)}} & =a_{1} \mathbf{1}+a_{2}\left(b_{1} \mathbf{1}+b_{2} \hat{\boldsymbol{n}}\right), \\
& =\left(a_{1}+a_{2} b_{1}\right) \mathbf{1}+a_{2} b_{2} \hat{\boldsymbol{n}} . \\
\frac{\partial q}{\partial \boldsymbol{\varepsilon}_{n+1}^{(k)}} & =\sqrt{6} \widetilde{\mathrm{G}} \hat{\boldsymbol{n}}-3 \widetilde{\mathrm{G}}\left(b_{1} \mathbf{1}+b_{2} \hat{\boldsymbol{n}}\right), \\
& =-3 \widetilde{\mathrm{G}} b_{1} \mathbf{1}+\widetilde{\mathrm{G}}\left(\sqrt{6}-3 b_{2}\right) \hat{\boldsymbol{n}} \\
\frac{\partial p_{c}}{\partial \boldsymbol{\varepsilon}_{n+1}^{(k)}} & =a_{3} \mathbf{1}+a_{4}\left(b_{1} \mathbf{1}+b_{2} \hat{\boldsymbol{n}}\right), \\
& =\left(a_{3}+a_{4} b_{1}\right) \mathbf{1}+a_{4} b_{2} \hat{\boldsymbol{n}} .
\end{aligned}
$$

$\hat{\boldsymbol{n}}$ の $\boldsymbol{\varepsilon}_{n+1}^{(k)}$ での偏微分 :

$$
\frac{\partial \hat{n}}{\partial \varepsilon_{n+1}^{(k)}}=\frac{2 \widetilde{G}}{\left\|S_{n+1}^{\text {trial }}\right\|}\left(I-\frac{1}{3} 1 \otimes 1-\hat{n} \otimes \hat{n}\right) .
$$

と式（88）の関係を（79）に代入することにより次式の Consistent 弾塑性構成テンソルを得る.

$$
\begin{aligned}
\overline{\mathbf{C}}^{e p}{ }_{n+1}^{(k)} & =2 \widetilde{\mathrm{G}} \boldsymbol{\xi}-\left(a_{1}+a_{2} b_{1}+\frac{2}{3} \widetilde{\mathrm{G}} \boldsymbol{\xi}\right)(\mathbf{1} \otimes \mathbf{1}) \\
& -a_{2} b_{2}(\mathbf{1} \otimes \hat{\boldsymbol{n}}) \\
& -\sqrt{6} \widetilde{\mathrm{G}} b_{1}(\hat{\boldsymbol{n}} \otimes \mathbf{1}) \\
& +\widetilde{\mathrm{G}}\left(2-\sqrt{6} b_{2}-2 \xi\right)(\hat{\boldsymbol{n}} \otimes \hat{\boldsymbol{n}})
\end{aligned}
$$

ここで $\xi=\sqrt{\frac{2}{3}} q /\left\|S_{n+1}^{\text {trial }}\right\|=\left\|S_{n+1}^{(k)}\right\| /\left\|S_{n+1}^{\text {trial }}\right\|$ である. 式 (90) の Consistent 弾塑性構成テンソルは，式 (33)， をNewton Raphson 法を行って解く場合に整合したもの であり，したがって 2 次収束を保証している。ここで $\Delta \phi \rightarrow 0$ とすると $\overline{\mathbf{C}}^{e p^{(k)}}$ は式(56)の (Continuum) 弾塑性 構成テンソルC ${ }^{e p}$ に一致する. 

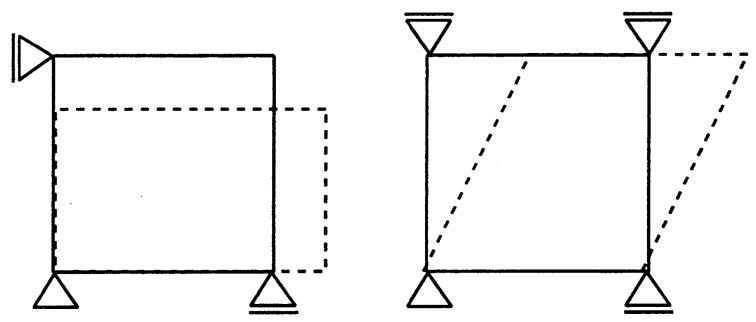

図一 2 等体積圧縮試験と純粋せん断試験.

表一 1 解析に用いた土質定数

\begin{tabular}{|c|c|}
\hline 圧縮指数 $\lambda$ & 0.15 \\
\hline 膨潤指数 $\kappa$ & 0.01 \\
\hline ポアソン比 $v$ & 0.3 \\
\hline 間隚比 $e_{0}$ & 0.1 \\
\hline 限界応力比 $M$ & 1.4 \\
\hline 透水係数 $k$ & 0.0 (非排水) \\
\hline
\end{tabular}

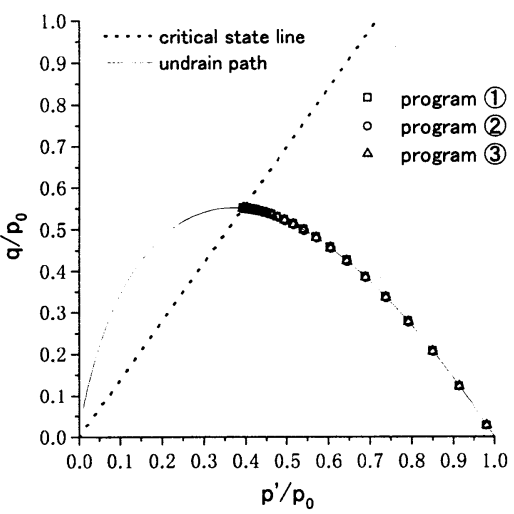

図一 3 等体積圧縮試験における平均応力と一般化せん断 応力 : 軸ひずみ増分 $\Delta \varepsilon_{22}=0.01 \% /$ step .

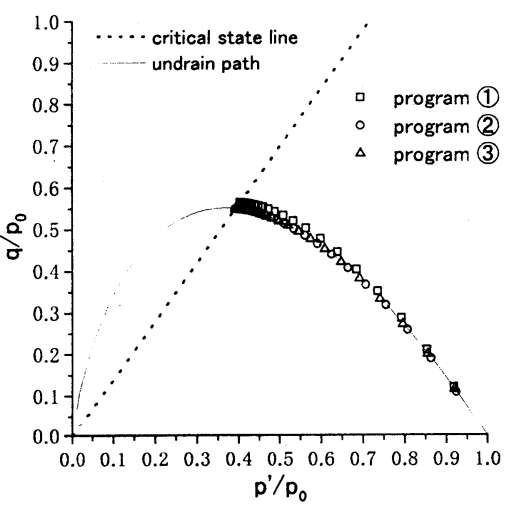

図一 4 等体積圧縮試験における平均応力と一般化せん断 応力 : 軸ひずみ増分 $\Delta \varepsilon_{22}=0.1 \% /$ step.

4. 陰解法弾塑性計算アルゴリズムを用いた土 / 水連成解 析の精度検証

本章では提案する陰解法弾塑性計算土／水連成解析の 精度および計算時間短縮が可能であることを検証する.

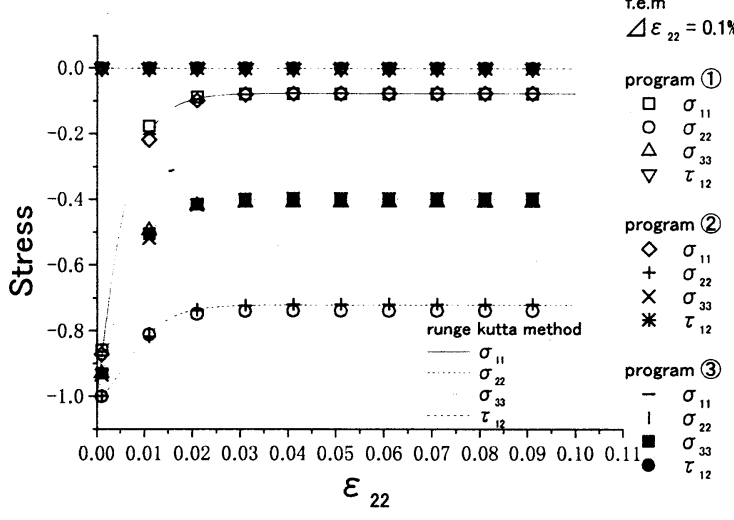

図一 5 等体積圧縮試験における各応力成分 : 軸ひずみ増 分 $\Delta \varepsilon_{22}=0.1 \% /$ step.

表一2 軸ひずみ $1 \%$ 時の Runge-Kutta 法に対する差.

\begin{tabular}{|c|c|c|c|}
\hline 軸ひずみ $1 \%$ & $\sigma_{11}$ & $\sigma_{22}$ & $\sigma_{33}$ \\
\hline プログラム(1) & $-10.1 \%$ & $+0.4 \%$ & $+1.9 \%$ \\
\hline プログラム(2) & $+9.5 \%$ & $+1.3 \%$ & $+3.0 \%$ \\
\hline プログラム(3) & $+1.1 \%$ & $+0.05 \%$ & $+0.3 \%$ \\
\hline
\end{tabular}

表一 3 軸ひずみ $10 \%$ 時の Runge-Kutta 法に対する差.

\begin{tabular}{|c|c|c|c|}
\hline 軸ひずみ $10 \%$ & $\sigma_{11}$ & $\sigma_{22}$ & $\sigma_{33}$ \\
\hline プログラム(1) & $+2.6 \%$ & $+2.6 \%$ & $+2.6 \%$ \\
\hline プログラム(2) & $-0.2 \%$ & $-0.2 \%$ & $-0.2 \%$ \\
\hline プログラム(3) & $-0.2 \%$ & $-0.2 \%$ & $-0.2 \%$ \\
\hline
\end{tabular}

比較に用いたプログラムは3つであり, Program(1)は式 （31）を用いて単に増分近似を行った陽解法プログラムで あり, Program(2), (3は本論文で提案する陰解法プログラ ムである.ただし Program(2)は弾塑性構成テンソルに式 (56)の Continuum 弾塑性構成テンソルを用いており, Program(3)は式(90)の Consistent 弾塑性構成テンソルを 用いたものである.

4.1 等体積圧縮試験解析と純粋せん断試験解析 (均一変形)

対象とした問題は図一 2 に示寸等体積圧縮試験と純粋 せん断試験である. それぞれ軸ひずみ，せん断ひずみが 10\%となるまで変位制御で載荷を行った. 用いた要素は 8 節点四辺形要素で変位は 8 節点で代表させ, 間隙水圧は四 辺形の頂点である 4 節点で代表させており, 均一変形であ るので 1 要素で行った. 用いた土質定数は表－1に示す. 残差は式 (46) 右辺の残差力ベクトルの2乗ノルムとし, その許容值は $1.0 \times 10^{-20}$ とした.

図一 3 , 図一 4 は等体積圧縮試験における平均応力と一 般化偏差ひずみの関係の図である. 図一 3 は軸ひずみ増分 を各ステップにおいて $0.01 \%$ とした場合で, 図一 4 は $0.1 \%$ とした場合である. 図中の曲線は非排水パスである. 図一 3 のように各ステップにおける軸ひずみを $0.01 \%$ と 比較的細かくした場合は, プログラム(1)〜3)のどの手法に おいても非排水パスと一致しており, 平均応力と一般化 


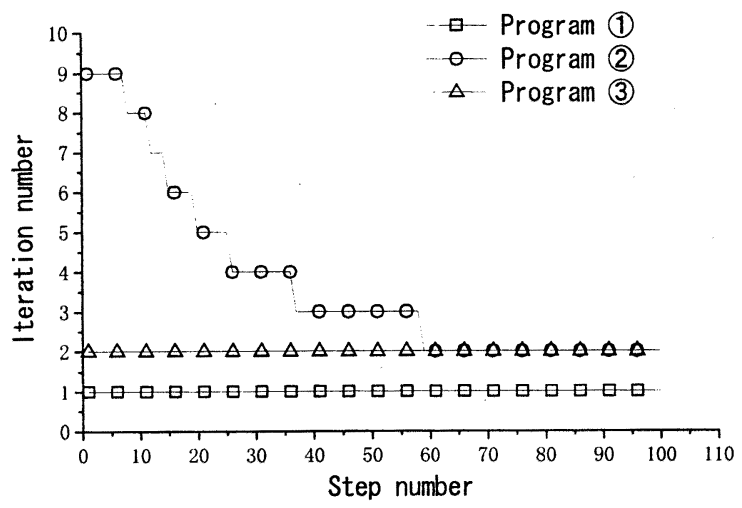

図一 6 等体積圧縮試験における各ステップの繰り返し 数 : 軸ひずみ増分 $\Delta \varepsilon_{22}=0.1 \% / \mathrm{step}$.

偏差ひずみの関係という意味においては精度よく解析で きていることが分かる. 図一4は各ステップの軸ひずみ増 分量を 10 倍ほど粗くした場合である. プログラム(2)と(3) は軸ひずみ増分量を 10 倍粗くしても解析結果は非排水パ スと良く一致しているが, プログラム(1)結果は軸ひずみ が増えるにつれて非排水パスの上側に明らかに離れてい っていることが分かる.この最終的に必要な境界条件まで 何ステップで解析するかは解析者の主観・判断に依存する ものであるが, この例ではプログラム(1)ように単に増分 解析を行うよりもプログラム(2)と(3)のように本論文で提 案するような implicit return mapping を用いる方が精度 を落とすことなく比較的粗い増分刻みを選ぶことが可能 であることが分かる. 図一 5 は等体積圧縮試験における軸 ひずみに対する各応力成分の変化である. 横軸は軸ひずみ 量であり, 縦軸は各応力成分である. 図中曲線は Runge -Kutta 法を用いて求めた各応力成分の変化であり, 記号 は各プログラムにより解析された值である.この Runge -Kutta 法は増分量に対する打ち切り誤差が 5 次精度であ ることが保証されている方法であり,均一変形の問題を解 く上では非常に精度が良い. 図一 4 のような平均応力と一 般化偏差ひずみの関係だけでなく, 各応力成分においても プログラム(2)と(3)の方法は精度が良いことが示されてい る. 表一 2 , 表一 3 にそれぞれのプログラムで求めた各応 力成分の Runge-Kutta 法に対する差を示した. 表一 2 は 軸ひずみが $1 \%$ 時であり，表一 3 は軸ひずみが $10 \%$ 時 である. 表一 1 より分かるようにせん断初期（軸ひずみが 1\%）においてはプログラム(1)と(2)は同程度の差であった が，プログラム(3)は約 10 分の 1 程度の差であった. 表一 3 はある程度応力が一定值に達した軸ひずみが $10 \%$ の時 の差であり,プログラム11では誤差が残っているが，プロ グラム(2)では誤差が小さくなり修正されていることが分 かる. これは implicit return mapping 党行っている効果 であると考えられる．注目すべきは implicit return mapping と Consistent 弾塑性構成テンソルを併用したプ ログラム(3)では応力の変化が大きいせん断初期において も, 限界応力比に近く応力がほぼ一定值に到達したせん断 終了時においても非常に精度が高いことが分かる.

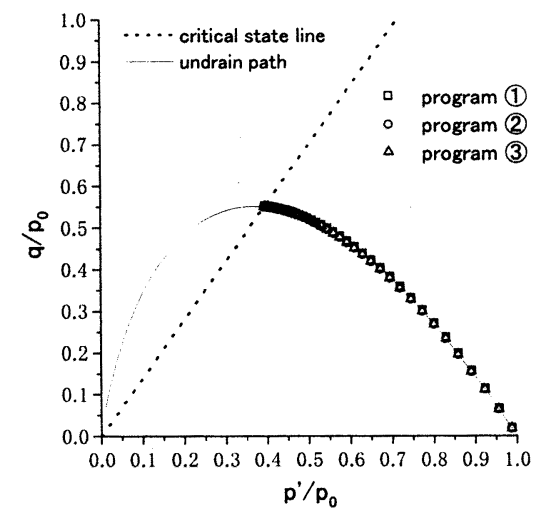

図一7 純粋せん断試験における平均応力と一般化せん断 応力 : せん断ひずみ増分 $\Delta \gamma_{12}=0.01 \% /$ step .

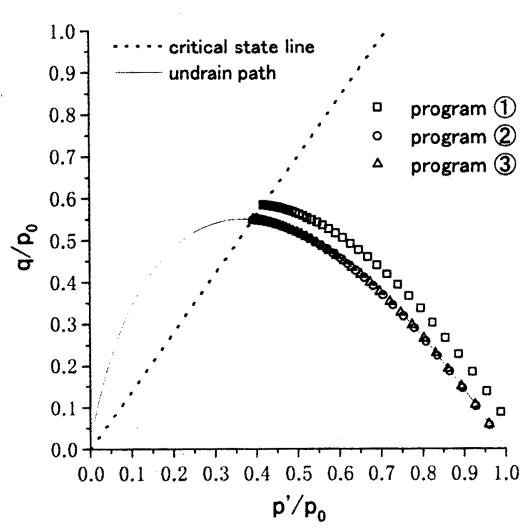

図-8 純粋せん断試験における平均応力と一般化せん断 応力 : せん断ひずみ増分 $\Delta \gamma_{12}=0.1 \% /$ step .

図一 6 は各ステップにおける軸ひずみ増分を $0.1 \%$ た場合の, 残差力が許容誤差内に収まるまでの収束にかか る繰り返し回数 (イタレーション回数) である. 有限要素 法の場合, 解析途中におけるリメッシュ（最適化などによ る再メッシュ）がなければ未知数の数は変化せず，1回の イタレーションにかかる時間はほぼ一定となる.よってこ のイタレーション回数が計算時間に結びつくことになる.

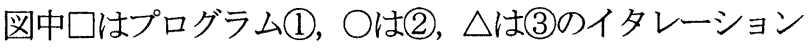
回数である. プログラム(1)においては残差力を減じる収束 計算を行っていないために各ステップにおいてイタレー ション回数は 1 回で斉み, 最も計算時間は短い. しかし, 前述したように精度の面では好ましくないので，その選択 には注意が必要である. プログラム(2)とプログラム(3)の結 果を見てみると,プログラム(2)においてはせん断初期にお いて 9 回ほどのイタレーション回数が必要であり, せん断 が進むにつれてその回数は減少しており, 総じて 370 回の イタレーション回数となった. プログラム(3)においてはせ ん断初期から終了までイタレーション回数は各ステップ で 2 回でよく, 総じて 200 回のイタレーション回数となり プログラム(1)の約 2 倍, プログラム(2)の約半分となった.

図一7, 図一8は純粋せん断試験を行った際の平均応力 と一般化せん断応力の関係である. 図一 7 はせん断ひずみ 


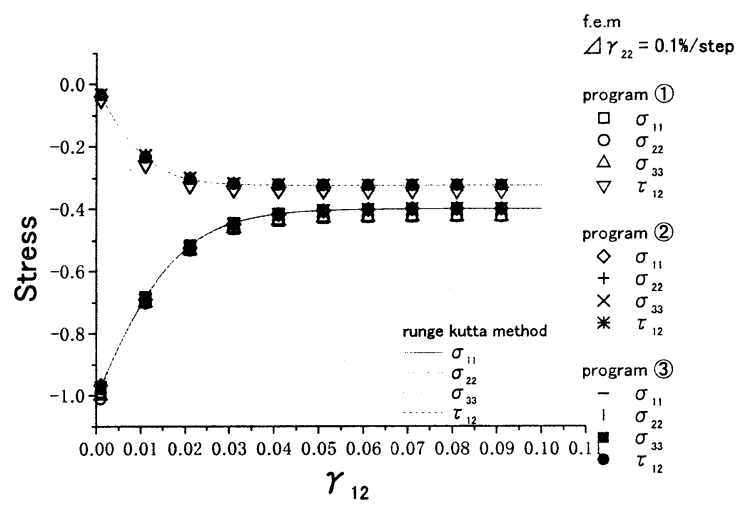

図-9 純粋せん断試験における各応力成分 : せん断ひず み増分 $\Delta \gamma_{12}=0.1 \% /$ step .

表一4 せん断ひずみ $1 \%$ 時の Runge-Kutta 法に対する差.

\begin{tabular}{|c|c|c|c|c|}
\hline $\begin{array}{c}\text { せん断ひず } \\
\text { み } \%\end{array}$ & $\sigma_{11}$ & $\sigma_{22}$ & $\sigma_{33}$ & $\tau_{12}$ \\
\hline $\begin{array}{c}\text { プログラム } \\
\text { (1) }\end{array}$ & $+2.4 \%$ & $+2.6 \%$ & $+2.5 \%$ & $+11.0 \%$ \\
\hline $\begin{array}{c}\text { プログラム } \\
\text { (2) }\end{array}$ & $+0.9 \%$ & $+1.2 \%$ & $+1.0 \%$ & $-2.0 \%$ \\
\hline $\begin{array}{c}\text { プログラム } \\
\text { (3) }\end{array}$ & $-0.2 \%$ & $+0.02 \%$ & $-0.1 \%$ & $+0.1 \%$ \\
\hline
\end{tabular}

表一 5 せん断ひずみ $10 \%$ 時の Runge-Kutta法に対する差.

\begin{tabular}{|c|c|c|c|c|}
\hline $\begin{array}{c}\text { せん断ひず } \\
\text { み } 10 \%\end{array}$ & $\sigma_{11}$ & $\sigma_{22}$ & $\sigma_{33}$ & $\tau_{12}$ \\
\hline $\begin{array}{c}\text { プログラム } \\
\text { (1) }\end{array}$ & $+6.2 \%$ & $+6.3 \%$ & $-5.9 \%$ & $-5.9 \%$ \\
\hline $\begin{array}{c}\text { プログラム } \\
\text { (2) }\end{array}$ & $-0.1 \%$ & $-0.1 \%$ & $-0.1 \%$ & $-0.1 \%$ \\
\hline $\begin{array}{c}\text { プログラム } \\
\text { (3) }\end{array}$ & $-0.1 \%$ & $-0.1 \%$ & $-0.1 \%$ & $-0.1 \%$ \\
\hline
\end{tabular}

増分が各ステップにおいて $0.01 \%$ とた場合であり, 図一 8は $0.1 \%$ とした場合である. どちらも最終的なせん断ひ ずみは $10 \%$ まで変形させた. 図一 7 のように比較的増分 刻みを細かくするとプログラム(1), (2)，(3)の結果はどれも ほぼ一致し, 非排水パスとも良く一致している. しかし, 図一8のように増分刻みを若干粗くするとプログラム(2), (3)では非排水パスと良く一致しているが, プログラム(1)で はせん断初期から非排水パスの上側に離れていることが 示されている.これよりせん断初期で発生した誤差がその まま残存し，以降修正されていないことが分かる. プログ ラム1のようなreturn mapping などの修正を行わない解 析においては, 特にひずみに対して応力の変化の大きくな るせん断初期には増分刻みを小さくする注意が必要であ る.

図一9は純粋せん断試験におけるせん断ひずみに対す る各応力成分の変化である. 図中各曲線が Runge-Kutta 法による解であるが, プログラム(2)，(3)の各応力成分は良 く一致しているが, プログラム(1)の各応力成分はどの成分

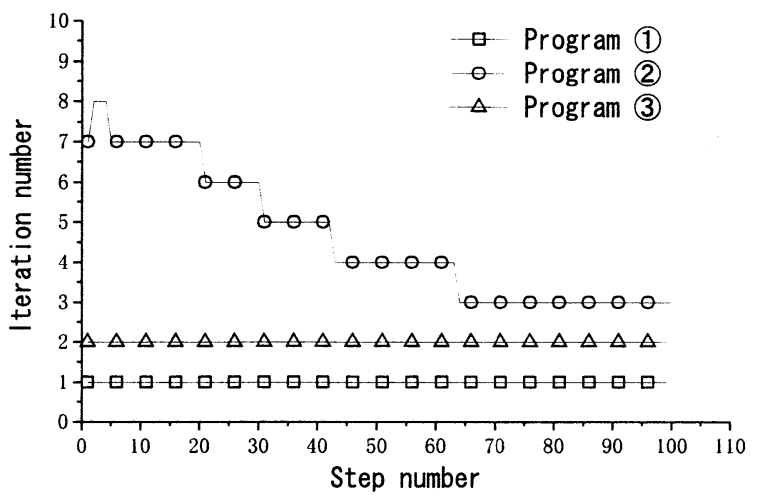

図-10 純粋せん断試験における各ステップの繰り返し 数 : 軸ひずみ増分 $\Delta \gamma_{12}=0.1 \% /$ step .

も Runge-Kutta 法の解に対して大きな差がある. 表一 4 ， 表一 5 にせん断ひずみが $1 \%$ と $10 \%$ の時の Runge-Kutta 法による解に対する各応力成分の差を示した. 表一 4 より せん断初期（せん断ひずみが 1\%）においてはプログラム (1)では差があり, 特にせん断応力に大きな差がある. implicit return mapping を行っているプログラム(2)では 1\%〜2\%の差があり, さらに Consistent 弾塑性構成テン ソルを併用しているプログラム(3)ではその差は $0.1 \%$ 前後 と非常に小さいことが分かる. 表一 5 にはせん断終了時 （せん断ひずみが 10\%）の Runge-Kutta 法に対する差が 示してあるが, プログラム(1)では各応力成分において約 6\%の差であるのに対して, プログラム(2)と(3)では $0.1 \% と$ 非常に小さく精度が良いことが分かる.

図一10は各ステップにおけるせん断ひずみ増分を $0.1 \%$ とした場合の, 残差力が許容誤差内に収まるまでの収束に かかる繰り返し回数 (イタレーション回数) である. 図中

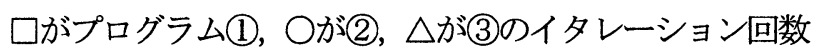
である. プログラム(1は等体積せん断試験解析の時も述べ たが, 各ステップでイタレーション回数は 1 回で良く, 最 も短時間て解析を終了できるが, 精度に関しては注意が必 要である. プログラム(2)では全ステップでのイタレーショ ン回数を総計すると 458 回となり, プログラム(3)では 200 回となった.

以上より速度型つり合い式と連続式を弱形式化し, 離散 化する事によって単に陽解法増分解析を行った場合は, 解 析者の判断に委ねられる増分刻み数の取り方によっては 著しく誤差を含むことがあることを例としてあげ, 本論文 で用いた implicit return mapping 手法は, 増分刻みを比 較的粗くしても精度を落とすことがなく, また Consistent 弾塑性構成テンソルを併用することにより短時間でより 精度良く解析できることが分かった。

\section{2 斜面変形解析 (不均一変形)}

前節において Runge-Kutta 法を用いて精度良く各応力 成分を解析できる均一変形である等体積圧縮試験と純粋 せん断試験を対象として取り上げ, 本論文で提案する陰解 法弾塑性計算アルゴリズムを用いた土/水連成解析の有 


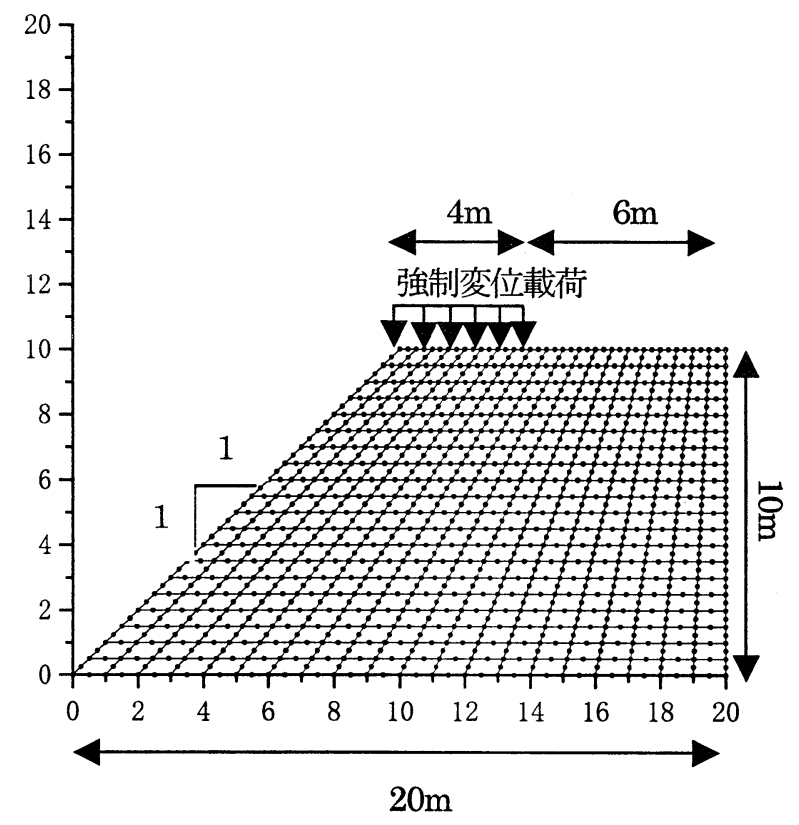

図-11 斜面解析有限要素モデル。

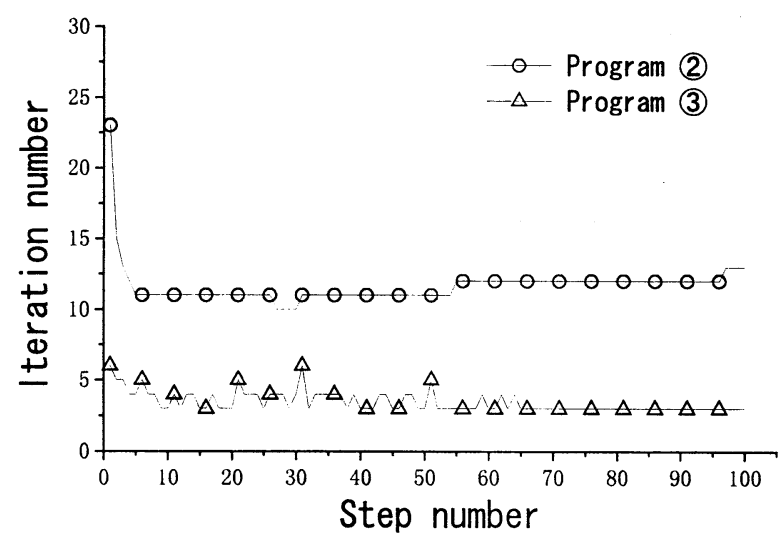

図-12 斜面変形解析における各ステップの繰り返し数.

用性を述べた. 本節においては特に Consistent 弾塑性構 成テンソルを用いることの有用性を明らかにするため, 不 均一変形である斜面変形解析を行う. 比較に用いたプログ ラムけ前節で用いた(2)と(3)と同样のものであり，雨プログ ラムとも implicit return mapping を用いているが，違い は構成マトリクスにあり，プログラム(2)では式 (56) で示 した Continuum 弾塑性構成テンソルを用いており, プロ グラム(3)では式 (90) で示した Consistent 弾塑性構成テ ンソルを用いていることである. 用いた有限要素モデルは 図一11に示したものである.

有限要素は前節と同様の 8 節点四辺形要素で, 変位は 8 節点, 間隙水圧は頂点の 4 節点で代表させており, 全要素 数は 400 要素である. 強制変位は盛土上面の法肩から $4 \mathrm{~m}$ までの範用に, 最終的に $0.1 \mathrm{~m}$ 沈下させるように載荷した. 初期先行圧密応力は $3.0[\mathrm{kPa}]$ とし, 初期間隙水圧は静 水圧分布とした. 解析に用いた土質定数は表一 1 と同

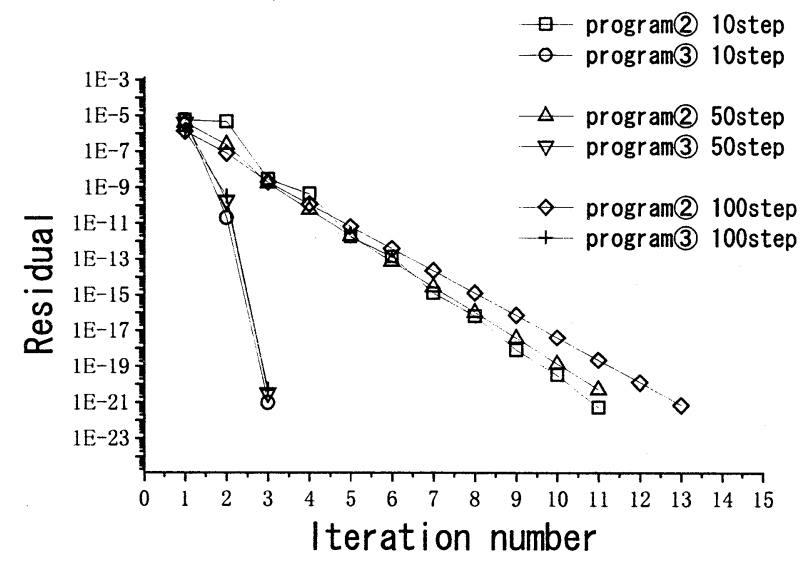

図-13 斜面変形解析における代表ステップの残差の収束 状況.

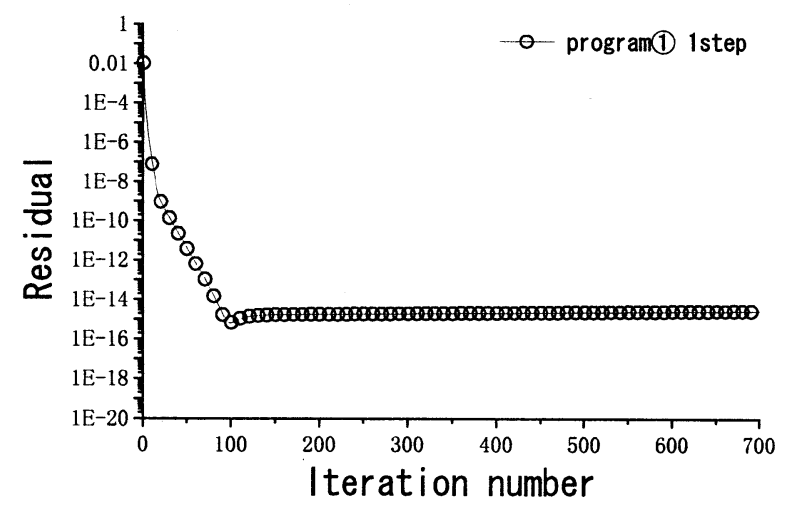

図-14 program(1)の 1step 目における残差の収束状況.

様である. しかし透水係数は $\kappa=2.22 \times 10^{-6}[\mathrm{~m} / \mathrm{min}]$ とし， 物体の境界では非排水であるが, 物体の内部では自由に間 隙水が移動できるものとした. 解析は $0.1 \mathrm{~m}$ 沈下までを全 100 ステップで行い, したがって各ステップの強制変位増 分は $1 \mathrm{~mm}$ である（ $\Delta \bar{u}=4.8 \mathrm{~m} \times 10^{-4}[\mathrm{~m} / \mathrm{min}] ）$. 残差は 前節と同様で式 (46) 右辺の残差力ベクトルの 2 乗ノルム とし，その許容值は $1.0 \times 10^{-20}$ とした.

図一12 は各ステップにおける残差が許容誤差に収まる までに要する繰り返し回数 (イタレーション回数)を表し たものであり, 横軸がステップ数, 縦軸がイタレーション 回数である. 図中, ○がプログラム(2), $\triangle$ が(3)のイタレー ション回数である. 明らかにプログラム(3)の方が解析全体 を通して少ない回数で収束していることが分かる. プログ ラム(2)は解析全体で 1165 回 (1 ステップ平均約 12 回) で あり, プログラム(3)では 344 回（1 ステップ平均約 4 回） であった. すなわち Consistent 弾塑性構成テンソルを用 いることにより約 $1 / 3$ の時間で解析が終了することになる. ちなみに当研究室で DOS/ N パソコン (CPU クロック数 : $1 \mathrm{GHz}$ メモリ：512MB）を用いて数值実験を行ったとこ ろ, 解析開始から解析終了までプログラム(2)では約 97 時 間, プログラム(3)では約 29 時間であった.

図一13 は代表的なステップにおける残差の収束状況を 
表したものである. 図中に代表として示したのは 10,50 , 100 ステップであり，プログラム(2)ではそれぞれ口， $\triangle$, ৩で示され，プログラム(3)ではそれぞれ $， \nabla ，+$ で示し てある. 横軸はイタレーション回数, 縦軸は残差の対数で あるが, どのステップにおいてもプログラム(2)では直線的 に減少するが, プログラム(3)では上に凸な放物線的に減少 している.このことより Consistent 弾塑性構成テンソル は全体の Newton Raphson 法に整合しており，2次収束 することが確かめられた. なお，陽解法のプログラム(1)の 場合, 繰り返し計算を行ったところ, 図一14 のように解 析初期の 1 ステップ目でイタレーション回数が 100 回程 度までは, $1.0 \times 10^{-16}$ 程度まで残差は減少を続けているが $1.0 \times 10^{-15}$ 程度でほぼ横ばいとなった. 正確には残差は微 量ながら増加しており, 以後, 解析を続行してみたが残差 の許容值 $1.0 \times 10^{-20}$ には到達しなかった.このような多要 素の問題では, 残差の許容值 $1.0 \times 10^{-20}$ はかなり厳しい条 件であるにも関わらず, 陰解法の場合は必ず収束し, 陽解 法の場合は収束しないことが分かった. 数学的には陰解法 はアルゴリズム解の無条件安定性が保証されているが, 陽 解法ではその保証が無いことの例証である ${ }^{3)}$.

5. まとめ

本論文では陰解法弾塑性計算アルゴリズムを取り入れ， 離散化された全体の非線形連立剛性方程式を Newton Raphson 法に整合させた土/水連成解析法を開発した.

これを従来から用いられている単純な陽解法 (但し連続式 は陰解法) 定式化による解析法と比較すると以下の点が明 らかになった。

1. 均一変形で精度良く解析できる Runge-Kutta 法と比 較することにより, 従来の速度型つり合い式と連続式 を弱形式化し離散化した陽解法増分解析手法では, 解 析者の判断による増分刻みの取り方により著しく精度 が落ちる. 一方, return mapping 手法を用いた本論文
で提案した陰解法によると増分刻みを比較的粗くして も精度良く解析できることが分かった.

2. return mapping 手法に併用して Consistent 弾塑性構 成テンソルを用いると計算時間の短縮だけでなく, さ らに精度が向上することが分かった.

3. 本報告の例での不均一変形で多要素解析の場合 Consistent 弾塑性構成テンソルを用いるか否かで 3 倍 ほど計算時間に差ができる事が分かった. 具体的には 本解析の場合, 計算時間の差は当研究室の数值実験で は Consistent 弾塑性構成テンソルを用いることによ り，約 4 日が約 1 日に短縮できた

4. Consistent 弾塑性構成テンソルを用いると全体の Newton Raphson 法に整合しているため, その残差が 2 次収束することが証明出来る. 本数值解析において もそれが例証できた.

なお， 今回は紙面の都合で割愛したが，陽解法の場合に も応力が降伏関数にのるよう種々の return mapping 手法 が考えられる. 著者らもいくつか試みたが, 収束の安定性, 収束の早さ, 計算時間いずれにおいても本報告で提案した 陰解法の方が優れていた。

参考文献

1) R. I. Borja and S. R. Lee : Cam-Clay plasticity, Part I : Implicit integration of elasto-plastic constitutive relations, Compt. Methods Appl. Mech. Engrg. 78(1), pp.49-72, 1990.

2) 土木学会海岸工学委員会研究現況レビュー小委員会 : 海底地盤の力学挙動, 海岸波動, pp.457-459, 1994.

3) 例えばJ.C. Simo, T.J.R.Hughes : Computational Inelasticity, Springer-Verlag New York, 1998.

4) J. C. Simo, J. G. Kennedy and S. Govindjee : Non-smooth multisurface plasticity and viscoplasticity. Loading/ unloading conditions and numerical algorithms, Internat. J. Numer. Methods Engrg 26, pp.2161-2185, 1988.

(2001年4月 20 日 受付) 